ORCID ID: https://orcid.org/0000-0001-8033-8877

Венка-Ведєнкіна П. Д., Одеський національний університет ім. I.І. Мечнікова

\title{
ДЕЯКІ ОСОБЛИВОСТІ РЕАЛІЗАЦІЇ ОРХУСЬКОЇ КОНВЕНЦІЇ НА МАЛЬТІ ТА В УКРАЇНІ: ПИТАННЯ ЗЕЛЕНОЇ ДЕМОКРАТІЇ
}

\begin{abstract}
Предметом статті є процес реалізації положень Конвенції СЕК ООН «Про доступ до інформачїі, участі громадськості в прочесі прийняття рімень та доступі до правосуддя з питань, щзо стосуються довкілля» (Орхуської конвенції). Дана стаття є результатом багаторічного інтересу автора до питань екологічної демократії, а також досвіду роботи в мальтійській природоохоронній НУО (BirdLife Malta), велика частина роботи якої здійснюється саме на виконання Орхуської конвенції. Автор ставить за мету зробити спробу загального порівняння процесу імплементації документу в Україні та державі СС (Мальті) з тим, щоб виявити певну специфіку та тенденції, а також запропонувати рекомендації для покращення стану імплементачії. Стаття базується на таких фундаментальних поняттях як зелена (екологічна) демократія, право на інформачію та вільний доступ до правосуддя з питань довкілля, механізми участі громадськості в процесі прийняття рішень. Порівняння будується на вивченні останніх наявних доповідей двох краӥн щзодо прогресу імплементації конвениії, а також приймаючи до уваги результати двох експертних опитувань, проведених автором в 2013 та 2020 роках. Перш за все розкриваються деякі важливі формально-прочесуальні аспекти прочесу імплементачії: інститучійні особливості та розподіл відповідальності, нормативно-правовий каркас, сформований країнами з метою імплементації принципів конвенщії. Наступна частина статті поділена на підрозділи, кожен з яких фокусується на особливостях реалізації кожного з прав, які захищає Орхуська конвениія на Мальті та в Украӥні: права на доступ до інформаиії, участь громадськості в прочесі прийняття рішень та доступ до правосуддя з питань, що стосуються довкілля. Крім порівняння мальтійського та украйнського досвідів у відповідній сфері, автор також намагається виявити деякі тендениї̈ та зміни, характерні саме для України.
\end{abstract}

Ключові слова: Орхуська конвенція, зелена демократія, екологічні права, механізми участі, екологічна інформачія, екологічна освіта, довкілля, доступ до правосуддя

На даному етапі розвитку людство впритул підійшло до екологічної катастрофи: проблеми, пов'язані зі станом навколишнього природного середовища, набули настільки гострого характеру, що потребують нагальних заходів, постійного моніторингу та вивчення для того, щоб попередити або нівелювати наслідки негативних змін. Оскільки екологічні проблеми є транскордонними та глобальними, задля їх ефективного вирішення з'явилась необхідність прийти до консолідованої позиції всіх країн світу. У другій половині XX ст. міжнародне співтовариство почало об'єднувати зусилля та вести активну роботу в сфері захисту природних ресурсів та боротьби із негативними змінами довкілля, причиною яких є антропогенні чинники.

Поступово екологічні питання були інтегровані в найрізноманітніші сфери життя суспільства: так, вже 3 70-х років минулого століття міжнародні природоохоронні акти пов'язують проблеми довкілля із правами людини. Наприклад, один із принципів Ріо-де-Жанейрської декларації (1992) захищає право громадян на участь в процесі прийняття рішень в сфері природоохорони та природокористування [1]. 3 метою реалізації даного принципу в 1998 р. була підписана Орхуська конвенція (далі ОК) - Конвенція СЕК ООН «Про доступ до інформації, участі громадськості в процесі прийняття рішень та доступі до правосуддя з питань, що стосуються довкілля».

Працюючи в природоохоронній організації BirdLife Malta, в силу своїх обов'язків, автор була безпосереднім чином задіяна в процес реалізації положень ОК на Мальті, зокрема в рамках механізму участі. Одночасно із цим, ОК також виступала предметом одного з попередніх досліджень автора, фокус якого був направлений на проблеми імплементації документу в Україні.

Сутність ОК може бути проілюстрована таким поняттям як екологічна (або зелена) демократія, оскільки документ захищає право кожної людини на здорове довкілля через гарантування таких 
фундаментальних прав, як: право на доступ до інформації, право на участь громадськості в процесі прийняття рішень, право на доступ до правосуддя з питань, що стосуються довкілля [2].

Конвенція проголошує критичну важливість стану природного середовища для здоров'я та життя людини, а також для реалізації її основних прав, включаючи саме право на життя - таким чином, вона гармонійно поєднує в собі екологічні та політичні аспекти життєдіяльності суспільства. 3 однієї сторони, цей документ виступає адвокатом довкілля, а з іншої- сприяє процесам демократизації через надання громадськості інструментів впливу на процес прийняття рішень. Це, в свою чергу, створює необхідні умови для підвищення якості зв'язку між громадянським суспільством та державою. Іншою особливістю конвенції є спільна відповідальність держави та суспільства за стан довкілля.

Комітет з дотримання, створений в 2002 р. виконує несудовий консультаційний нагляд за виконанням конвенції (в його склад входить 9 незалежних експертів). Окрім Комітету, іншим важливим органом ОК виступає Секретаріат. Від відповідальний за адміністративні питання, а також розгляд доповідей Сторін щодо прогресу в реалізації конвенції. Ці доповіді мають надаватись Сторонами кожні 3 роки. До слова, остання українська доповідь, опублікована на офіційному сайті ОК, датується 2014 р., в той час як Мальта, разом із абсолютною більшістю інших країн-сторін конвенції, надала останню доповідь в 2017 p., а на даному етапі проводить консультації 3 громадськістю щодо проекту доповіді 2021 p.

Автор має наголосити, що в даній статті буде посилатись на українську доповідь 2014 р., та мальтійську доповідь 2017 р. Цей недолік деяким чином буде нівельовано, включивши до аналізу дані експертного опитування, проведеного в рамках даного дослідження в 2020 р., та попереднього дослідження 2013 p.* а також наявну аналітичну інформацію з відповідного питання.

На Мальті органом, відповідальним за імплементацію ОК, є Управління з питань довкілля та ресурсів (ERA), яке входить в систему органів Мінприроди. Такий підхід демонструє дотримання принципів субсидіарності та пропорційності, характерних для європейської політики загалом. Подібний розподіл повноважень, по-перше, сприяє більш якісному виконанню завдань, наданих конвенцією, по-друге, підвищує рівень відповідальності та підзвітності органів.

В Україні ж Мінприроди як таке $\epsilon$ основним координатором імплементації ОК. Одночасно 3 цим, при Державному екологічному інституті був створений Орхуський центр - інформаційно-тренінгова платформа 3 питань, що стосуються положень конвенції. Нажаль, активність центру практично непомітна для загальної публіки: платформу було створено в 2003 р., але вона й досі не має власного веб-сайту або окремої сторінки на офіційному сайті Мінприроди. Можна знайти аккаунт Орхуського центру в Фейсбук, але, враховуючи мету та напрямки діяльності центру, назвати його інформаційнопросвітницьку роботу на цьому ресурсі єфективною також не можна - на сторінку підписано менше 1000 людей.

Достуn до інформаиії. Перше, що кидається в очі при аналізі національних доповідей, це список нормативно-правових документів, що імплементують положення ОК в країні. Так, на Мальті основним відповідним документом є закони Про захист довкілля та Про регулювання планованої діяльності. Ці два закони - фундамент, що підтримує заснований на правах людини підхід, проголошений конвенцією. Окрім них, є два закони, що надають громадянам право на доступ до інформації. В Україні також було прийнято кілька законів та підзаконних актів 3 метою сприяння прозорості та оперативності інформування громадян [3;4]. В цілому, судячи 3 оцінок експертів (опитування 2013, а також 2020 рр.) ситуація із доступом до інформації в Україні $\epsilon$ доволі сприятливою, якщо порівнювати із двома іншими аспектами конвенції. Процедурні умови прозорого надання інформації на Мальті іноді ускладнюють можливість отримання екологічної інформації, проте загалом ця частина ОК виконується належним чином.

В рамках гарантування права на вільний доступ до інформації, п. 3 ст. 3 конвенції закликає країни активно сприяти екологічній просвіті населення, адже розуміння екологічних основ життя $\epsilon$ необхідною умовою участі громадськості в процесі прийняття рішень. В українській доповіді йдеться про те, що з метою реалізації згаданого пункту держава розробила концепцію екологічної освіти. Зокрема, перелічена низка освітніх заходів, що були здійснені у звітний період - більша частина активностей носить характер саме курсів за вибором або факультативних занять [5]. Й досі в системі середньої освіти немає загальнообов'язкової дисципліни з питань стійкого розвитку, природокористування, або екології.

Мальтійський досвід в цьому відношенні значно відрізняється: шкільна програма там формується за принципом міждисциплінарності, а навчання протікає в рамках кількох тематичних блоків, в тому 
числі блоку «Освіта задля стійкого розвитку». Такий підхід не лише відповідає принципам ОК, але й сприяє зміні навчальної практики, коли знання, отримані за шкільною партою, перестають бути фрагментованими (як в рамках традиційного підходу), а учнів заохочують задіювати навички iз різних сфер пізнання [6]. Серед іншого, це означає, що шкільна програма має потужну практичну складову. Крім цього, дякуючи деякій автономності учбових закладів, у мальтійських шкіл $€$ можливість розширити програму, залучаючи зовнішніх експертів та організації. Прикладом успішної реалізації аспекту конвенції, пов'язаного з екологічною просвітою, може слугувати програма Dinja Waћda, яка здійснюється BirdLife Malta в мальтійських школах [7]. Цьому проекту вже більше 20 років, і він направлений саме на поглиблення екологічної освіти школярів різного віку завдяки проведенню позакласних занять та практичних семінарів (в рамках шкільної програми) на території заповідників. На таких заняттях діти отримують не лише теоретичні знання, але й можуть самостійно переконатись в їх доцільності, спостерігаючи в бінокль за мігруючими птахами, життям колонії комах або ставлячи експеримент про особливості руйнування пластику в природному середовищі. Крім навчання школярів, проект також надає тренінги для вчителів відповідних дисциплін, а також залучає школи до участі в суботниках.

На думку автора, фундаментальна різниця між українським та мальтійським підходом полягає у відношенні до шкіл як суб'єктів освітнього процесу. В Україні школи мають низьку автономію, особливо коли мова йде про зміст освітніх програм, іх розширення, наприклад, за рахунок практичного компоненту або залучення НУО та зовнішніх експертів. 3 іншої сторони, мальтійські школи, крім направленості на отримання емпіричного знання, мають значно більшу незалежність від центру, відповідно, навчальні програми відкриті додатковому та інноваційному, завдяки чому вони стають більш різноманітними.

Окрім пункту, що заохочує Сторони підвищувати рівень екологічної освіти, ОК визначає основні критерії ефективного та прозорого інформування громадськості з питань, що стосуються довкілля. Експертне опитування 2013 р. продемонструвало, що в Україні ситуація з доступом до інформації знаходиться на задовільному рівні завдяки розробленості нормативно-правової бази, а повторне опитування 2020 р. показує, що стан речей в Україні залишається незмінним. І хоча в цілому ситуація $\epsilon$ позитивною, тим не менш, існує низка недоліків: наприклад, якщо йдеться про надання інформації на запит громадян, то рівень імплементації конвенції доволі високий, проте якщо ми говоримо про поширення та відкритість екологічної інформації, то він низький (приклад із згаданим вище Орхуським центром показовий). В 2018 р. Мінприроди ініціювало запуск національної платформи «Відкрите довкілля», яка в підсумку запрацювала завдяки скоординованій роботі громадянського суспільства та державних органів, і на даний момент включає кілька інтерактивних мап (наприклад, «Вода», «Повітря»), які містять технічні дані з моніторингу стану довкілля [8]. В основі створення цієї платформи лежить ідея зібрати якомога більше екологічної інформації в межах однієї бази для зручності користування та забезпечення прозорості надання даних. Ця інформаційна база поки знаходиться на стадії розвитку та наповнення, проте в процесі спеціалісти стикаються з низкою перешкод (невідповідність та розбалансованість даних, неповні дані, відсутність взаємодії між різними інституціями по части обміну інформації і т.ін.) [9]. В рамках опитувань, українські експерти відмічали, що проблема імплементації ст. 4 ОК також полягає в низькому рівні поінформованості органів влади та судових органів 3 питань, що стосуються конвенції, що створює додаткові перешкоди на шляху успішної реалізації екологічних прав громадян.

Ситуація з доступом до інформації на Мальтійських островах схожа: існує необхідна законодавча база, що надає громадянам право отримувати екологічну інформацію. Крім цього, функціонує низка порталів, що містять дані екологічного моніторингу: наприклад, портал, що відслідковує забруднення повітря за різними показниками в реальному часі, а також геопортал, що містить інформацію про розташування водних об'єктів, містобудівну інформацію, обмеження на будівництво та здійснення промислової діяльності, об'єкти природно-заповідного фонду і т. ін. [10;11]. Тим не менш, за експертними оцінками ситуація з доступом до інформації все ще не до кінця відповідає керівним принципам ст. 5 ОК. Зокрема, відсутність єдиної бази екологічної інформації призводить до непрозорості всієї системи: до прикладу, інформація, що стосується планованої діяльності, розподілена між двома відомствами (ERA и Planning Authority), та часто надається в неповному обсязі, що, зрозуміло, створює перешкоди для зацікавленої громадськості. При цьому, неповноту даних державні органи часто пояснюють прагненням не розкривати конфіденційну (приватну) інформацію, хоча існує ціле різноманіття інструментів, що дозволяє керувати інформацією таким чином, щоб приватні дані лишались нерозкритими, в той час як публічна інформація залишалась 
у вільному доступі. Крім цього, політична експертка Я. Лаурент наголошує, що в роботі державних органів на Мальті можна прослідкувати тенденцію до нерозуміння або некоректної інтерпретації статей ОК, що разом із непогодженістю роботи різних відомств призводить до неефективного управління та поширення екологічної інформації.

Участие в прочессе принятия решений. В межах опитування 2013 р. більшість українських експертів відмічали, що в той час як ситуація з доступом до екологічної інформації була достатньо непогана, громадськості не вистачало механізмів для користування своїми правами на участь в процесі прийняття рішень, та доступ до правосуддя по відповідним питанням. Лише після довгих консультацій із НУО та лобіювання зі сторони громадянського суспільства, було підписано два важливих закони, які надали громадянам відповідні інструменти: Про оцінку впливу на довкілля (далі ОВД) (2017) та Про стратегічну екологічну оцінку (2018). На Мальті ці закони були прийнято в 2017 та 2010 рр. відповідно, крім цього держава сформувала ряд інших актів, що розкривають різни аспекти механізму участі (всього 8 основних документів).

Отже, за оцінками експертів, в Україні після прийняття згаданих вище законів, помічено позитивні здвиги в ситуації з участю громадськості в процесі прийняття рішень. Серед яскравих прикладів, варто згадати відкриття державного порталу Єдиного реєстру ОВД, де можна знайти всю документацію, що формується в процесі оцінки [12]. Тим не менш, експерти відмічають, що нерідко громадські обговорення залишаються формальністю та не відіграють покладеної на них ролі в процесі прийняття рішень.

На Мальті практична реалізація законів щодо участі громадськості можлива завдяки онлайн порталу, де зацікавлені громадяни та резиденти можуть заповнити офіційну форму в рамках консультацій з приводу планованої діяльності, а також знайти відповідну документацію [13]. Нажаль, на власному досвіді автор мала змогу з'ясувати, що нерідко інформація на порталі $є$ неповною. У випадку, якщо на консультацію подаються законопроекти, зміни до них або масштабні будівельні проекти, на окремі стадії консультацій дається до 2 місяців, в інших випадках - 2-3 тижні. Не дивлячись на те, що з формальної точки зору принципи конвенції дотримуються, реалізація права участі на практиці може бути ускладнена через декілька причин: серед іншого, неефективна система анонсування консультацій, неможливість від слідкувати результати та отримати зворотній зв'язок не завжди зрозуміло, чи була прийнята думка громадськості до уваги, а якщо ні, то з якої причини, i т.ін. Крім цього, помітна неузгодженість системи участі громадськості: в одних випадках консультації проводять через згаданий портал, в інших - необхідно направити коментар на електронну пошту працівника певного відомства, що робить весь процес менш прозорим. Більше того, за власними спостереженнями автор упевнилася, що протягом року існують періоди, коли анонсується найбільше консультацій, в такому разі державні органи могли б йти на зустріч громадянам та збільшувати період для участі в консультаціях - особливо істотно це відчувають НУО, які за родом своєї діяльності постійно приймають участь в обговореннях того чи іншого проекту, або закону. Одночасно з цим, мальтійська експертка, відмічає, що з роками система стає більш відкритою до діалогу з громадськістю. Показовим прикладом може слугувати оголошення істотної частини акваторії Мальти заповідною зоною, що було ініційовано природоохоронними організаціями.

Доступ до правосуддя. Що стосується забезпечення вільного доступу до правосуддя (ст. 9 ОК), в 2005 р. в Україні був прийнятий закон, покликаний підвищити прозорість судової практики [14]. Нажаль, ситуація з доступом до правосуддя з екологічних питань залишається складною, особливо якщо справа йдеться не про оскарження порушення права на інформацію, а інших аспектів екологічного законодавства. За думкою експертів, проблема полягає в загальній недосконалості судової системи України, а також відсутності широкої судової практики з питань, що стосуються довкілля. Одночасно з цим, адвокат Д. Скрильніков відмічає позитивні зміни в судовій практиці вищого рівня (Верховного Суду), що, вважається, вплине на прийняття рішень з цих питань в майбутньому [15]. Також варто відмітити, що створення Єдиного реєстру судових рішень важливий крок до відкритості судової системи. Однак реєстр не є зручним у користуванні, крім цього, частина справ, що стосуються екологічного законодавства все ще лишається невеликою. Проте дякуючи роботі НУО «Екологія. Право. Суспільство», громадськість отримала можливість доступу до тих рішень реєстру, які стосуються довкілля [16].

На Мальтійських островах діє 4 закони, що захищають право громадськості на оскарження дій чи бездіяльності суб'єктів, які негативно вплинули (або можуть вплинути) на довкілля. На Мальті практика користування правом на доступ до правосуддя - дещо більш поширена, ніж в Україні, проте i тут не без труднощів. Серед найчастіших перешкод в доступі до правосуддя - недостатність, або 
закритість екологічної інформації. Так BirdLife Malta подала до суду на Управління з питань диких птахів саме у зв'язку з ненаданням інформації за запитом. При цьому, суд постановив, що через деякі технічні труднощі, дана інформація не могла бути надана. Приймаючи до уваги ст. 9 та ст. 5 ОК, держава повинна створити зрозумілу та повну систему екологічних даних, а ії відсутність не може слугувати причиною ненадання екологічної інформації. Таким чином, судове рішення $\epsilon$ необгрунтованим, та буде оскаржено BirdLife Malta до кінця року. В цілому, мальтійські НУО мають широкий досвід участі в судових слуханнях з питань довкілля, а також ініціювання окремих судових справ (наприклад, про порушення національного та європейського законодавства щодо відкриття сезону полювання та його особливостей і т. ін.). Той факт, що громадськість активно реалізує своє право на доступ до правосуддя, створює відповідну судову практику, а також підвищує обізнаність суспільства з екологічних питань.

\section{Висновки}

Порівняння досвіду реалізації положень ОК в Україні та на Мальті дозволяє зробити наступні висновки:

1. Організаційно-прочедурного характеру: обидві держави впевнено розвивають свою законодавчу базу з метою імплементації конвенції, проте, не дивлячись на формальні досягнення, обидві країни стикаються з деякими труднощами, що призводять до зниження ефективності виконання принципів ОК на практиці. Серед національних особливостей можна виділити дещо більш розмиту відповідальність за впровадження положень ОК в Україні; та деяку неузгодженість між різними відомствами щодо розуміння принципів конвенції, на Мальті.

2. Інформачійно-освітнього характеру: в Україні все ще немає практики адекватного, повного та своєчасного інформування громадськості з екологічних питань, обмін інформацією між інституціями не налагоджений, рівень компетентності чиновників з питань конвенції лишається невисоким. Одночасно із цим справедливо буде відмітити в цілому позитивну ситуацію з доступом до екологічної інформації за запитами. Екологічна освіта в Україні лишається формальною та факультативною, статичність навчальних програм заважає розвитку ініціатив. Мальта, в цілому відповідаючи принципам ОК, тим не менш не вирізняється ефективним управлінням екологічною інформацією; і хоча низка державних порталів містить різноманітні дані екологічного моніторингу, та іншу екологічну інформацію, часто вона лишається неповною або іїі важко відслідкувати.

3. Суспільно-діяльнісного характеру: значного успіху досягли як Україна, так і Мальта в забезпеченні механізмів участі в процесі прийняття рішень- відповідні закони надали громадськості інструменти впливу. Тим не менш, не дивлячись на прописані правила та процедури, участь нерідко виявляється ускладненою (як у зв'язку із слабкою інформованістю населення щодо консультацій, так і в контексті доступу до результатів). Серед національних особливостей можна відмітити більш активну позицію громадянського суспільства на Мальті як з питань участі, так і доступу до правосуддя; та відносно низьку активність суспільства в Україні, де практика громадської участі знаходиться на етапі становлення. Доступ до правосуддя 3 екологічних питань лишається найскладнішим аспектом реалізації ОК в обох країнах. В Україні ця ситуація ускладнюється нерозвиненою судовою практикою з відповідних питань, а на Мальті - неефективною комунікацією та непрозорістю системи управління екологічною інформацією.

4. Рекомендаційного характеру: ОК надала суспільству реальні механізми впливу на процес прийняття рішення в екологічній сфері, інструменти протягування сторін до відповідальності за порушення природоохоронного законодавства та, як наслідок, можливість активно реалізовувати своє право на здорове довкілля. В цьому контексті, звичайно, рівень розвинутості громадянського суспільства - значущий чинник ефективної реалізації принципів конвенції. Повне та якісне інформування, прозорість процесу отримання екологічної інформації - другий важливий аспект цього питання. Обидві держави мають створити єдину та відкриту електронну базу, що буде містити наявні екологічні дані, показники, та нормативні документи. Для України критичним лишається питання екологічної освіти та розвитку практичної, міждисциплінарної складової навчального процесу на виконання ст. 3 ОК. 3 метою підвищення участі громадськості в обговореннях, бажано створити (розвинути) відповідну платформу, де міститиметься актуальна інформація щодо консультацій, супроводжена відповідною документацією, формою зв'язку для участі онлайн та результатами обговорення. I останнє, проте вкрай важливе - необхідно створювати судову практику з питань ОК, що фундаментальною умовою успішного виконання принципів ОК, підвищення обізнаності, відповідальності та екологічної свідомості населення. 


\section{Примітки:}

* Експерти (2020): Андрусевич А., старший аналітик РАЦ «Суспільство і довкілля»; Скрильніков Д., адвокат «Бюро екологічний розслідувань», член Комітету з дотримання ОК; Лаурент Я., експертка з політичних питань BirdLife Malta (2016-2020); представник ERA (ім'я не розголошується).

\section{Бібліографічний список:}

1. Рио-де-Жанейрская декларация по окружающей среде и развитию. URL: https://www.un.org/ru/documents/decl_conv/declarations/riodecl.shtml (дата звернення: 10.12.2020).

2. Full text of the Convention. URL: https://unece.org/environment-policypublic-participation/text (дата звернення: 15.11.2020).

3. Закон України «Про інформацію». URL: https://zakon.rada.gov.ua/laws/show/2657-12\#Text (дата звернення: 15.11.20).

4.Закон України «Про звернення громадян». URL: https://zakon.rada.gov.ua/laws/show/393/96$\% \mathrm{D} 0 \% \mathrm{~B} 2 \% \mathrm{D} 1 \% 80 \#$ Tехt (дата звернення: 15.11 .20 ).

5. Reporting mechanism. 2014 National Implementation Reports. URL: https://unece.org/environmentpolicypublic-participation/reporting-mechanism (дата звернення: 05.11.20).

6. Malta. Organisation of the Education System and of its Structure. URL: shorturl.at/egBMN (дата звернення: 05.11.20).

7. BirdLife Malta. Schools. URL: https://birdlifemalta.org/environmental-education/schools/ (дата звернення: 06.11.20).

8. Open Access Environment. Мапи. URL: http://openenvironment.org.ua/index.htm (дата звернення: 19.11.20).

9. Старт роботи нової онлайн бази екологічних даних «Відкрите довкілля». URL: https://openaccess.org.ua/news/view/1008 (дата звернення: 02.12.20).

10. ERA. Data from Air Monitoring Stations. URL: https://era.org.mt/topic/real-time-air-quality-network/ (дата звернення: 18.11.20).

11. Planning Authority. Map Server. URL: http://geoserver.pa.org.mt/publicgeoserver (дата звернення: 18.11.20).

12. Єдиний реєстр з оцінки впливу на довкілля. URL: http://eia.menr.gov.ua/ (дата звернення: 18.11.20).

13. Public Consultations Online. URL: https://meae.gov.mt/en/Public_Consultations/Pages/Home.aspx (дата звернення: 08.11.20).

14. Закон України «Про доступ до судових рішень». URL: https://zakon.rada.gov.ua/laws/show/3262-15\#Text (дата звернення: 12.11.20).

15. Верховний Суд. «Конституційне право на безпечне довкілля належить кожному», - Олександр Прокопенко. URL: https://supreme.court.gov.ua/supreme/pres-centr/news/660584/ (дата звернення: 12.11.20).

16. Реєстр судових рішень 3 питань, що стосуються довкілля. URL: http://caselawepl.org.ua/ (дата звернення: 12.11.20).

\section{References:}

1. Rio-de-Zhaneyrskaya deklaratsiya po okruzhayuschey srede i razvitiyu. URL:

https://www.un.org/ru/documents/decl_conv/declarations/riodecl.shtml (data zvernennya: 10.12.2020).

2. Full text of the Convention. URL: https://unece.org/environment-policypublic-participation/text (data zvernennya: 15.11.2020).

3. Zakon UkraYini «Pro InformatsIyu». URL: https://zakon.rada.gov.ua/laws/show/2657-12\#Text (data zvernennya: 15.11.20).

4.Zakon UkraYini «Pro zvernennya gromadyan». URL: https://zakon.rada.gov.ua/laws/show/393/96-vr\#Text (data zvernennya: 15.11.20).

5. Reporting mechanism. 2014 National Implementation Reports. URL: https://unece.org/environmentpolicypublic-participation/reporting-mechanism (data zvernennya: 05.11.20).

6. Malta. Organisation of the Education System and of its Structure. URL: shorturl.at/egBMN (data zvernennya: 05.11.20).

7. BirdLife Malta. Schools. URL: https://birdlifemalta.org/environmental-education/schools/ (data zvernennya: 06.11.20)

8. Open Access Environment. Mapy. URL: http://openenvironment.org.ua/index.htm (data zvernennya: 19.11.20).

9. Start roboti novoYi onlayn bazi ekologIchnih danih «VIdkrite dovkIllya». URL: https://openaccess.org.ua/news/view/1008 (data zvernennya: 02.12.20).

10. ERA. Data from Air Monitoring Stations. URL: https://era.org.mt/topic/real-time-air-quality-network/ (data zvernennya: 18.11.20).

11. Planning Authority. Map Server. URL: http://geoserver.pa.org.mt/publicgeoserver (data zvernennya: 18.11.20).

12. Ediniy reEstr z otsInki vplivu na dovkIllya. URL: http://eia.menr.gov.ua/ (data zvernennya: 18.11.20).

13. Public Consultations Online. URL: https://meae.gov.mt/en/Public_Consultations/Pages/Home.aspx (data 
zvernennya: 08.11.20).

14. Zakon UkraYini «Pro dostup do sudovih rIshen». URL: https://zakon.rada.gov.ua/laws/show/3262-15\#Text (data zvernennya: 12.11.20).

15. Verhovniy Sud. «KonstitutsIyne pravo na bezpechne dovkIllya nalezhit kozhnomu», - Oleksandr Prokopenko. URL: https://supreme.court.gov.ua/supreme/pres-centr/news/660584/ (data zvernennya: 12.11.20).

16. ReEstr sudovih rIshen z pitan, scho stosuyutsya dovkIllya. URL: http://caselawepl.org.ua/ (data zvernennya: 12.11.20).

\section{Venka-Viedienkina P. D., Some particularities of the Aarhus Convention implementation in Malta and Ukraine: the issues of green democracy}

The process of the Aarhus Convention implementation is the subject of this article. The article is a result of a long going interest of the author in the issues of green democracy, as well as a professional experience working in the Maltese environmental NGO (BirdLife Malta), whose big share of work is dedicated to the implementation of the Aarhus Convention provisions. The author aims at making an attempt to compare the specifics of the Aarhus Convention implementation process in Ukraine and the EU country (Malta) to define particularities and tendencies, as well as to suggest certain recommendations to improve or foster the state of implementation. The grounds of the article rests on such fundamental categories as green (environmental) democracy, the right to environmental information and free access to justice on environmental matters, mechanisms of public participation in decision making process. The comparison is built upon the study of the last available national reports on the progress of implementation in Ukraine and Malta, as well as on the results of two expert surveys conducted by the author in years 2013 and 2020. Firstly, certain important formal and procedural aspects of implementation process in the two countries are explained: institutional particularities and distribution of responsibilities; legislative framework formed by the countries to embed Convention principles into the national legislation. The next part of the article is divided into several paragraphs - each of them focuses on the specifics of different ecological rights guarantees and exercise in Malta and Ukraine: the right to access environmental information; participate in decision making; access to justice on environmental matters. Apart from comparing the Maltese and Ukrainian experience, the author also tries to define some trends and changes relevant for Ukraine itself.

Key words: the Aarhus Convention, green democracy, environmental rights, public participation mechanisms, environmental information, environmental education, access to justice 